\title{
Liability for Damage Caused by Administrative Vehicles in Cote d'Ivoire
}

\author{
Dro Hyacinthe Diomandé \\ University of Jean Lorougnon Guede of Daloa, Daloa, Cote d'Ivoire \\ Email: Didro2017@gmail.com
}

How to cite this paper: Diomandé, D. H. (2021). Liability for Damage Caused by Administrative Vehicles in Cote d'Ivoire. Beijing Law Review, 12, 1095-1108. https://doi.org/10.4236/blr.2021.124056

Received: October 13, 2021

Accepted: December 3, 2021

Published: December 6, 2021

Copyright $\odot 2021$ by author(s) and Scientific Research Publishing Inc. This work is licensed under the Creative Commons Attribution International License (CC BY 4.0).

http://creativecommons.org/licenses/by/4.0/

\begin{abstract}
Today in many respects, liability for damage caused by administrative vehicles makes it possible to perceive another facet of the litigation of administrative liability. This responsibility is an a priori act that provides for the laws enacted by officials of the administration of the Republic of Cote d'Ivoire in case of administrative offenses in the field of traffic. However, it is a dispute that far beyond presenting an exceptional nature and regime undermines through its regime derogating from common law, the very autonomy of administrative responsibility. It is indeed one of the disputes that, having struggled to obtain a certain autonomy vis-à-vis the common law, continue to return to its starting point. Indeed, the problem is the existence of this litigation of responsibility, which in doctrine is an inevitable source of doctrinal differences, as to the legal and contentious nature of its regime in states with duality of jurisdiction. This article of constructivist essence, aims to show the weaknesses of the decision-making mechanism responsibility in case of damage, the responsible for the administration and the perpetrator of the damage. The results revealed the question of administrative liability for damage caused by the vehicle, based on special derogating rules.
\end{abstract}

\section{Keywords}

Administrative Vehicles, Responsibility, Administrative Law, Damage, Republic of Cote d'Ivoire

\section{Introduction}

The principle of the separation of judicial and administrative powers, set out in article 13 of the law of 16-24 August 1790 (Montesquieu, 1979: p. 296), was fully affirmed later, with the Blanco judgment of the Tribunal of Conflicts of 1873, thus seemed to provide historically, with this judgment, a real basis for the au- 
tonomy of administrative responsibility vis-à-vis the responsibility of ordinary law. This growing responsibility for evolution has some deviations from its original principle of existence. Such a reality is explained by the fact that legal theory and practice seem to return somewhat to the original foundations established; and this, through the interference of the private in the public, the judicial in the administrative and even that of judicial jurisdiction in administrative matters (Truchet, 2007: pp. 633-645). This is the case of several disputes including the one that relates to the general perspective of the object of our study: the litigation of administrative vehicles. Liability is understood to mean the obligation of a person to assume a fault and the resulting damage through possible compensation (Lalou, 1928: p. 479).

At the theoretical level, they seemed to reflect divergent political traditions: on the one hand, a paradigm of the checks and balances theory of government in which the State is subjected to control by the ordinary courts of the land and liability imposed according to the normal rules; on the other hand, a classic example of Separation of Powers in which the executive is immunised from "harassment" by the judiciary and can be used only in special administrative courts staffed by administrative officials, the best known and most prestigious of which is the Conseil d'Etat. Modern writers had suggested that this French model had led to a synthesis between the two great administrative law actions (le recours pour exces de pouvoir and le recours de pleine juridiction), which had fused into a coherent system of administrative law with great potential for control of executive abuse of power. At a technical legal level, too, the systems seemed to afford a sharp contrast. When other systems emphasized the personal liability of individual public servants such in England, while for example Cote d'Ivoire stressed the corporate liability of the State, which finds expression in the idea of maladministration or "faute de service" (fault in the administrative system). Previous writers had suggested that this concept was better tailored to the needs of government liability and afforded the subject a better chance of compensation. A second difference was the greater willingness of Cote d'Ivoire administrative jurisdiction to impose strict liability which, it was suggested, had in some areas virtually superseded fault as a basis of liability, again affording a better chance of success. It seemed logical to suppose, therefore, that this system would prove, in practice and in theory, that a clear preference would emerge; and that a straight choice could be made between this system in Cote d'Ivoire and others. At a time when other administrative law was noticeably introspective and searching feverishly for new solutions, merely to establish the facts seemed useful.

At the doctrinal level, too, the systems in Cote d'Ivoire, in China or in France are more similar than dissimilar. Both are in fact predominately fault based. Where differences emerge, as for example, in the important case of risk liability, these differences turn out not to be features peculiar to French public law which in fact closely resembles French private law. The differences are not, therefore, necessarily attributable to any inherent difference in the nature of "public" and 
"private" liability; they may equally spring from differences between the French civilian system and the English common law system of civil liability.

Liability may be civil, criminal, administrative, contractual, tort, political, etc. From this definition, we can see two aspects of responsibility explained by Catherine PUIGELIER (Puigelier, 2020b: p. 919). It is about the consistency and facets of the notion. First, from the point of view of consistency, responsibility refers to a legal obligation on the part of a person.

Since this obligation consists of liability for a fault committed and the damage resulting therefore, liability thus, as a matter of principle, cannot exist without the commission of fault and damage caused to others. It is also a major notion of Law, given that its mere mention is consistent with the idea of reparation for damage caused, the idea of justice that the Law must ensure in the face of the abuses of a third party. It makes it more practical to understand the definition of Law engraved in the Digest by CELSUS in these terms "law is the art of good and just" (Puigelier, 2020b: p. 919). So, if the law is for justice, then the law is for the courts for the purpose of claiming justice. From this, it is understood through the notion of responsibility that litigation is consubstantial to Law because the latter fully serves the expression of the latter in the realization of its purpose. Secondly, the initial definition of responsibility shows that it is a concept that is broken down in several disciplines of law. It therefore has several facets that adapt its initial meaning according to the legal branch that approaches it. Thus, while civil liability consists in repairing the damage often by means of monetary compensation and proclaiming the nullity of the acts performed, criminal liability consists in suffering custodial sentences and provisional measures. Both tend strongly to punish and repress the perpetrator of the harmful act (Saleilles, 1897: p. 56). Even if the manners differ from each other, the purpose is the same. From the foregoing, it emerges that the notion of liability as stated above is a notion specific to private law. However, liability will thus be extended to public law towards the end of the nineteenth century with the Blanco judgment of the conflict Tribunal (Bardonnet, 1957: p. 209) which enshrines the existence of liability of legal persons under public law. The very one that is the subject of our reflection.

As affirmed, it is understood that responsibility in its implementation leads to the identification and conceptualization of a notion that is both close and fundamental to it. This is the concept of damage. According to the legal dictionary (Dégni-Segui, 2012: p. 448), the notion of harm refers to the notion of harm (Dégni-Segui, 2009: p. 384). For the author of the book, harm is the damage suffered by a victim and likely to be repaired. This apprehension might seem obscure if it were not clarified. Harm thus appears as the infringement of a legally protected interest of a person; only an infringement capable of making the damage a simple objective fact at the outset remediable. It follows that any damage is not repairable or compensable. But any harm is compensable and repairable. The doctrine agrees to identify three types of damage: personal injury, property damage and moral damage (McBRIDE, 2009: pp. 340-342).

But no matter what kind of damage may be, it can only be repaired on the 
condition that it causes harm, and therefore that it undermines the legitimately protected interests of a person.

Moreover, it is appropriate to dwell on the concept of administrative vehicles. In administrative law, administrative vehicles are therefore vehicles specific to the Administration, vehicles that belong to the Administration. These are vehicles owned by the administration. But if the administrative term is clearer, the concept of vehicle has a rather complex meaning for which there is a need to resort to a relatively long development. In general, a vehicle is defined as a mobile device used to transport people and goods (Mazeres, 1960b: pp. 620-624). A legal analysis of this initial definition reveals two criteria for the legal definition of the concept of vehicle. The broad and extensive definition of the vehicle is the one that is adopted in this matter, especially by judges when confronted with specific cases. This is apparent from an analysis of the case law on this subject. This is because the broad definition puts much more emphasis on the function of carrying. In this, the vehicle appears as any machine that serves to transport people and goods. This definition is that adopted by jurisprudence in the context of the application of another law, that allocating jurisdictional powers in the matter of litigation of damages of any kind caused by any vehicle.

It is therefore an extension of the concept of vehicle to different cases, according to the judge's in concreto assessment. Thus, it pleases jurisprudence to integrate into the concept of vehicle "a river dredge, a ferry, even an airplane ..." The notion is here extensively explained. It is semantically deployed for greater ease in the application of the law for which the judge proceeded to such a broad interpretation of the vehicle (Puigelier, 2020b: p. 919). However, it is not only this interpretation of the judge that strikes. But another from which it is accepted that the case law has retained the name Motor Land Vehicle (VTM) in the context of the application of a law in France which guarantees compensation to victims in the event of traffic accidents (Puigelier, 2020a: p. 341).

In Côte d'Ivoire, the administrative vehicle refers to any vehicle (car or motorcycle) used by the government in the performance of its task. They are more specifically called "Vehicle D" and are managed by the Administrative Vehicle Management Office (BGVA) (Lath, 2011: p. 1281).

These vehicles are essentially made up of vehicles assigned to the Government and the Presidency of the Republic with the exclusion of vehicles assigned to the Ministry of Defense and public works machinery that are not supported.

The purpose of this study is to analyze the litigation of administrative vehicles in the light of legal texts and judicial practice and to understand the mechanism for compensating victims. Thus, the analysis resulting from it cannot be in vain and devoid of interest, since from the scientific point of view, litigation of damage caused by administrative vehicles is a dispute whose legal nature is particularly difficult to identify; but also that from a practical point of view victims of accidents involving an administrative vehicle are generally ignorant of compensation procedures. Thus, it is of dual interest to deal with this subject through this manual, the interest being intended to be scientific and practical. The scien- 
tific interest is clearly perceived in the production through this work of updated data on said subject. Although it is common and recurrent among judges (Long \& Weil, 1984: p. 638), this topic would seem to attract little interest from specialists in Ivorian administrative law. Reflecting on this topic could be a relevant indicator to re-evaluate and reinvigorate the management of this responsibility, which is apparently little understood by the public. Moreover, the practical interest of this study lies in the possibility of being available to public authorities who will be able to enrich themselves further with this work on the issue of litigation of administrative vehicles; as well as other services.

The administrative vehicle dispute is in principle an administrative dispute insofar as it involves the object of the administration: its vehicle. This topic thus introduces the generality of administrative responsibility. It is therefore supposed to be subject to the rules of public law and thus be within the competence of the administrative judge, it being understood that it is now a question of living the autonomy of said administrative responsibility. And yet several readings of the related documentation, it would be an administrative dispute derogating from the special rules of administrative responsibility (Mazeres, 1962a: p. 639).

Therefore, an irregular administrative dispute that is subject to civil law and censure of the judicial judge. The responsibility for damage caused by administrative vehicles would be a truly special responsibility of the Administration.

Thus, the theoretical foundations of liability for damage caused by administrative vehicles (I) will be progressively analyzed before its legal regime (II).

\section{Methodological Approach}

From a methodological point of view, the research was based on literature review. Indeed, the document analysis consisted of a localization of the resources already processed on question of administrative liability for damage by an administrative vehicle. The main attention is paid to the notion of administrative responsibility in terms of the phenomenon of law and the institution of law. The author justifies the expediency of introducing the application of coercive measures of the administrative head, the principle of the inevitability of liability for damage caused by an administrative vehicle, the distribution of powers, tasks and responsibilities between the units of the organization, its personnel and the state in contemporary administrative law. This would make it possible to regulate the actions of administrative actors in the face of damage caused by the vehicle, which is necessary for the exact understanding of the corresponding categories. Also, the reflection was based on website consultation of the Court of Justice and the relevant national courts, as well as resource persons, who have been asked to make comments and observations that might enrich the original proposal.

Constructive method and juridical analysis were used in the research. Indeed this article is devoted to the examination of legal analysis, as one of the important tools to improve the efficiency of the functioning of the Ivorian administrative system in case of damage caused by the vehicle, as well as to the identifica- 
tion of legal technologies used for the purposes of legal analysis, their peculiarities and their interrelations (Direction Generale De La Decentralisation Et Du Developpement Local, 2000). The constructive method was to pay special attention to the implementation of legal analysis in administrative activities. This legal study is carried out on the formal, legal and structural basis of the Ivorian administration, governing the monitoring of the application of the law.

\section{Result}

The reliability of the results of the study is ensured by a representative source and information base, including scientific work in French and English, the use of modern methodological approaches and techniques.

The application of the methods used to analyze the issue of administrative liability for damage by an administrative vehicle also guarantees the reliability of the results obtained.

\subsection{The Legal Basis for Liability Due to Administrative Vehicle}

In Ivory Coast, judicial practice easily demonstrates two bases of administrative responsibility, whereby the judge engages the responsibility of the administration in the event of damage caused by administrative vehicles. In the first case, it advocates the requirement of proven fault, while in the second case; it evokes the presumption of responsibility of the Administration in its capacity as guarantor of the vehicle. To say that it will be a question of presenting administrative liability for fault (A) and administrative liability without fault (B) in case of damage caused by administrative vehicles.

\subsubsection{Administrative Liability for Misconduct}

The responsibility of public authorities for damage caused by administrative vehicles, the existence of which constitutes a necessary condition for liability, may be the responsibility of the Administration (1) itself, as well as that of the official employed by it (2).

\subsubsection{Administrative Liability for Fault Due to the Fact of Administration}

In order to speak of administrative responsibility due to the administration, it is necessary that a third person suffers an injury attributable to the Administration, caused by the fault of the latter through the use of his vehicle. Damage to be compensable does not have to be hypothetical. On the contrary, it must be very real and current, that is, fully and effectively suffered at the time of the claim for compensation (Dufau, 2000: p. 34).

Like the law of liability in France, in Ivorian law, hypothetical or possible damage on the other hand, is not remediable. This is the classic assumption of the harm suffered by the loss of luck at a contest. Some exceptions, however, have recently been attached to this principle in France. In addition to the certain damage that is compensable, the direct nature of the damage could be men- 
tioned. Indeed, direct damage is just as compensable as certain damage. Through this prejudice, the judge intends to compensate only the direct and immediate consequences of the prejudice imputed to the Administration. As such, the various forms of incapacity for work, medical expenses, excluding food and maintenance costs not caused by the injury suffered, are considered direct damages (Sieur, 1950: p. 413).

In addition, the judge also compensates without difficulty both material and moral damage. Material damage has always been considered repairable and does not raise any particular difficulties (Djan Ziago Joseph vs. Cote d'Ivoire, 1986). This is clearly the case for damage to movable or immovable property road centaurs mentioned above: damaged vehicle or personal injury resulting in incapacity. The jurisprudence of the Abidjan Court of Appeal is abundant and constant in this matter (Bleou, 1988: pp. 113-146).

It must be recalled in passing that until independence the administrative judge refused reparation for moral pain on the double grounds that it is impossible to prove and that "tears are not monetized". It then compensates the next of kin on the "basis of disturbances of any kind brought to their living conditions" while maintaining the principle on the grounds that "moral pain is not appreciable in money, does not constitute damage capable of giving rise to reparation.

French administrative law is innovative with the Letisserand judgment of 24 November 1961 (G.A, 102), in which the Council of State admitted for the first time, the principle of compensation for moral pain. In the present case, he held that the moral pain felt by a father following the death of his son "is in itself a source of prejudice" (Vedel, 1961: p. 98).

Also, for it to have fault of the administration, the harm must have a causal link with the administrative activity of a public person. This is called imputability of prejudice to the administration. This principle of liability for injury is based on causation. Here the responsibility of the Administration will be engaged only if there is a direct link of cause and effect between the damage and the administrative activity. The praetorian power of the judge is not negligible in this matter (Debbasch Charles et COLIN Frederic, 2010: p. 58). The latter admits that there is a causal link between the damage suffered by the victims of a coach accident and the negligence of the municipal administration resulting from the fact that the vehicle may have been put into operation without insurance. And, the activities in question that may involve the responsibility of the Administration must only be administrative.

\subsection{Administrative Responsibility for Personal Misconduct of the Public Official}

The personal fault of the officer who engages the latter's responsibility could occur in two cases. The agent may, commit the fault either outside the service or even in the service. It is necessary to distinguish here again according to whether or not the fault of the agent is "unrelated to the service" (Moreau, 1986: pp. 45-48). Where the fault of the officer was committed outside the performance of 
his duties and is unrelated to them, there is undoubtedly a personal fault. In general, this applies to the fault committed by the officer in connection with activities that are personal to him and in respect of which the service is not involved in any way. This is the case of the police officer who, when invited to a friend's house, fatally injures him by recklessly handling his weapon; it is also the case of the customs officer who, outside the exercise of his duties, but taking advantage of them (in uniform and carrying his weapon), arrests and, as a result of an altercation, mortally injures a person with whom he had a professional dispute. Such a fault is not the responsibility of the Administration, but of the agent who acted not as an agent of the Administration but as a human person with his passions and desires. Here, the only person who could be held responsible for this fault is the agent. As regards the system of fault not devoid of any link with the service, it is determined by the existence of damage and a preposition link, causal link of the latter with the service proving that the agent was indeed on assignment in the administrative vehicle at the time of the occurrence of the damage.

This is the fault of the officer who, even having been committed outside the public service, maintains spatial and temporal links with the latter (Duez, 1938: p. 76).

The most classic example is provided by automobile accidents caused by administration officials who used them for personal and off-duty purposes but refused to drop off a girl he was volunteering to transport hitchhiker, the latter panicked, jumped out of the vehicle and was fatally injured (Odent, 2007: p. 62). The public official also commits a personal fault when, being the driver of an administrative vehicle, he decides to take his mistress in a vehicle and, having deviated from the normal route of his mission to take her to his village, causes an accident in which she is injured. However, the fault of the officer committed in the service or even in the course of the service can very often pose a problem as to how could the fault of the service, attributable to the administration, be distinguished from the fault of the personal officer? This question, the judge identified a number of criteria for distinction, namely three separate criteria for "detecting" the personal fault of the officer, called detachable fault of the service. These include, among others, self-interest and bad intent as well as gross misconduct.

\subsubsection{A Responsibility Often Devoid of Fault}

This responsibility results from various hypotheses or "situations" that have in common to present exceptional hazards to the citizens. The administration that thus runs these risks and benefits from them must be held accountable for the harmful consequences that result. Damage is indeed, caused either by dangerous things or by dangerous situations. To talk about dangerous things that are causes of damage in terms of liability of administrative vehicles is to mention the risk(s) related to the use of the administrative vehicle. It is to make the administration responsible for the risks related to the use of its vehicle. Accidents that may oc- 
cur in particular when these vehicles are in full use. The theory of liability for risk generally applies to accidents caused by explosives or dangerous weapons. The Council of State thus decided in the ruling Regnault-Desroziers of 28 March 1919 (G.A. 38), with regard to an explosion produced in a military camp, it held that the accumulation of explosives in the vicinity of an agglomeration and their handling under sketchy organizational conditions "involved risks exceeding the limits of those that normally result from the vicinity and that such risks were of such a nature, in the event of accidents as to engage, independently of any fault, the responsibility of the state".

In addition, in SATMACI v. KRIPA Amoin, the Ivorian administrative judge held the administration liable on the basis of the principle of presumption of responsibility. This indicates the responsible administration not because of a fault, but because of its quality as the guardian of the vehicle. The administrative judge, reasoning as we mentioned above, puts the notion of administrative vehicle at the center of his argument (Bulletin Officiel Du Ministere Du Travail, De L'Emploi Et De La Formation Professionnelle, 1997). As has just been said, it is from the damage caused by the thing or property that the Administration has in its custody that it is responsible. Also, according to this principle of the presumption of responsibility, the administration is presumed responsible until its innocence is proved before the administrative judge.

The issue of dangerous situations is appreciated through reality certain risks related to the dangerousness of road traffic. They may relate to certain missions, as certain activities may be performed in particularly dangerous places. These administrative activities are thus called dangerous because they expose certain citizens to a particular, exceptional danger. The particularly dangerous nature of traffic could constitute a dangerous situation and therefore a risk because it could contribute to endangering human lives, exposing innocent people. Or some missions of the Administration involve some risks, which always remain very accentuated in terms of road traffic (Gaudemet, Stirn, Dal Farra, Rolin, 2008: p. 105).

\subsubsection{A Jurisdiction Discussed between the Administrative Judge and the Courts of Common Law}

It follows from the law which establishes the regime of liability for damage caused by administrative vehicles an exclusive attribution of the competence to know this dispute of liability to the judges of general law. But this competence is initially attributed to the administrative judge, would be tutored in judicial practice by the courts of common law.

\subsubsection{Jurisdiction Initially the Exclusive Prerogative of the Administrative Judge}

Administrative jurisdiction is based in the history of French administrative law. It is based on two elements. Namely, the law of 16-24 August 1790 which sets the tone through the separation of administrative and judicial authorities. Secondly, it is with the Blanco judgment that the foundation of administrative jurisdiction 
will have its full depth through the autonomy of administrative responsibility established by the judge of the Conflict Tribunal (Bardonnet, 1932: p. 212).

It is a question of saying that the administrative competence, therefore that of the administrative judge in view of its foundation, always retains its effectiveness since its affirmation. However, it now appears to be only historical in that the 1957 act establishes a regime other than that which is historically admitted (Frier Pierre-Laurent et Jacques PETIT, 2015: p. 93).

Although historically accepted, it seems with the advent of this law to lose power and effectiveness. The administrative jurisdiction in matters of liability for damage caused by administrative vehicles seems, with the law of 31 December 1957, no longer relevant. And this is what this law affirms in its content by providing those cases relating to administrative vehicles having been subject to censure by the administrative judge, prior to the advent of the 1957 law; remained within the jurisdiction of the administrative judge. The 1957 Act thus marked the beginning of the new regime of liability for damage caused by an administrative vehicle, not by annulling for the past the effects of principles prior to it, but by setting out a new framework in derogation of the main principles previously established. It is a dark hour for administrative law in that the basis of its autonomy is called into question by the legislator who wants to unify all disputes relating to vehicles. However, judicial practice in general, reveals a worrying reality causing the administrative judge to lose the rating to the detriment of ordinary courts.

According to this text, "the courts of the judicial order are only competent to decide on any action for liability tending to repair damages of any kind caused by any vehicle" (Bascoulergue, 2014: p. 311). The doctrine emphasizes that "the main idea, consistent with the drafting of the law and parliamentary debates, and which inspired the jurisprudence, was simple: to give this derogatory law as broad a scope as possible, with a view to completely unifying the litigation of traffic accidents", but that "this law has caused considerable litigation, especially on the part of the dispute tribunal, and the interpretation given to it periodically reveals new problems". The administrative court seems to lose its exclusive jurisdiction to the detriment of other courts.

\subsection{4. "Exclusive" Jurisdiction of the Administrative Judge, Ultimately Exercised by the Courts of Ordinary Law}

Article 1 of the 1957 law does not simply refer the dispute over administrative responsibility to the application of the judicial judge (Moreau, 1986: pp. 45-48). It goes far beyond that to avoid that, from an interpretative perspective, one leads to the division of jurisdiction in matters of administrative vehicle between administrative judge and judicial judge, the certainty being only its submission to the application of civil law. Far beyond that, it assigns exclusive jurisdiction to the courts to hear cases of this kind on the application of the common law of liability mentioned above. In view of this provision of the law, the administrative judge of our time could not and could not be competent to hear this dispute. 
Indeed Article 2 of the same law is clear on this subject. It provides, "The administrative court remains competent to rule on the actions before it has been seized, prior to the publication of this law, in connection with the damages referred to in Article 1 above". The law is clear, and the legislature now teaches us that this law has no retroactive effect; for it only applies to the future. It does not nullify the jurisdiction under which disputes of this kind long before its publication had been subject to censure by the administrative judge. The Ivorian judge would be under this law on a good run. He who already applies, as a judge of common law to this litigation of liability, the common law in matters of liability. The so-called judgment of the Bac of Eloka of 1983, is an illustration of the judicial jurisdiction retained in respect of a public service, therefore the Administration (Guillot, 1963: pp. 446-448).

In this case, a ferry belonging to the colony of Cote d'Ivoire established on the Ebrié lagoon which it used directly and personally by the Bassam wharf service. On the night of September 5-6, 1920, the ferry was crossing the lagoon, loaded with eighteen people and four automobiles, when it sank abruptly. By flowing sharply into the Ebrié lagoon, there is death of man and property damage: a native drowned and automobiles that were transported by the ferry are removed from the water "severely damaged" after a descent of these at the time of the accident in the depths of the lagoon. The société commerciale de l'Ouest africain, owner of one of these automobiles, summoned the colony before the court of Grand-Bassam; since the lieutenant governor of the colony had raised the dispute, the Dispute Tribunal decided that the dispute fell within the jurisdiction of the courts of justice. This case is of real interest to us in that it involves a BAC, which since the Barbou judgment of the Tribunal des Conflits of October 15, 1973, is considered a vehicle; and in the context of the Bac judgment of Eloka, a vehicle belonging to the former colony of Côte d'Ivoire (Guyomar Mattias et SEILLER Bertrand, 2012). Such a decision of the dispute tribunal is clearly in line with the legislation of 31 December 1957 relating to the litigation of the liability of vehicles. The civil judge is competent and can fully apply rules of his office to an administrative responsibility (Fauconnet, 1920: p. 45).

However, it is very remarkable in judicial practice that we encounter positions that are antagonistic to those expressed by the legislator on the question; these rules therefore suffer from the real problem of exclusivity with regard to judicial practice.

\section{Discussion}

Analysis of the issue of administrative responsibility is a type of legal liability faced by almost all legal entities and individuals. Measures of administrative responsibility, as well as criminal, are imposed by the state, but they are less strict than criminal ones and come for less dangerous acts (Demba, 2014: p. 14).

Administrative responsibility is the application of coercive measures of the 
administrative head to the perpetrator of an unlawful act. It arises from a socially dangerous offense or act and is a special administrative relationship (Moreau, 1957: pp. 802-803). Indeed, the implementation of administrative responsibility is carried out on the basis of law, specific penalties, and legal norms providing for the responsibility for this offense, hence the principle of inevitability. The legal norm teaches, warns, obliges to be extremely attentive and careful, that is, to show the necessary voluntary efforts, and in fact to anticipate the harm caused. Then, the establishment of liability should be carried out within the framework of a commission in the case of an administrative offense more precisely in the case of damage caused by an administrative vehicle (Thiebaut, 2019: pp. 215-256).

In this respect, the principle of the inevitability of responsibility means that no offense should remain unresolved, out of the view of the administrative manager. It therefore becomes a legal activity, also a legislative activity of the State in the event of force majeure. However, we note that in Cote d'Ivoire, the difficulty comes from the confusion of the distribution of responsibility for incidents caused by the individual with an administrative vehicle. While, the effectiveness of a damage management system is often determined by the distribution of powers, tasks and responsibilities between the units of the organization, its staff and the state (Tcheriatchoukine, 1996: p. 28).

The continental concept of abuse of rights is missing from the common law. Instead, the judges are left to manipulate the antiquated torts of conspiracy and of misfeasance in public office in Cote d'Ivoire. This creates uncertainty and ambiguity. There is no doubt that this area of the law of torts needs urgent attention from the Law Commission and the legislature. Because tortious liability in the common law was always exceptional, it was closely linked to fault, the idea of risk as a general basis for liability was discounted; indeed, until comparatively recently, strict liability was considered a medieval relic, unsuited to the conditions of a modern, industrial society.

To allow to the judges a power of compensation in the case of valid use of administrative power seems at first sight even more drastic. The Cote d'Ivoire experience demonstrates, however, that this is not really the case. Legality and illegality are relative and flexible concepts; compensation and liability are really alternative routes to the same destination. The real difficulty is to isolate any definite principle on which the courts could base their awards. The Cote d'Ivoire principle of Equality before public charges provides us with an illustration of the difficulties which our courts would face.

The process of delegation of tasks and authority is often overlooked or overlooked by administrative officials in the organization. In this case, the Ivorian administration should review the definition of the term liability at the state level as well as at the legal level, which can give power to the administrative official, the State or the individual who must assume responsibility for the damage caused (Lalou, 1928: p. 479). 


\section{Conclusion}

In real, it should be remembered from this subject that he introduced us to a little-known reality of administrative litigation (Laferriere, 1896). Liability for damage caused by administrative vehicles thus presented is halfway between public and private law. It clearly appears to constitute a departure from the main principles of the special law of administrative responsibility. The idea that the responsibility of administrative vehicles constitutes a point of conciliation, of meeting between administrative law and civil law; although classified in the generality of administrative responsibility, it makes the administration subject to a legal regime from which it has historically experienced a detachment (Schiemann, 2011: p. 55). Thus, juxtaposed in an oxymoronic relationship, these two terms give our subject an original allure insofar as in a deeper analysis we could see it as a place where public law and private law reconcile to reform the Law in its pure state.

\section{Conflicts of Interest}

The author declares no conflicts of interest regarding the publication of this paper.

\section{References}

Bardonnet, D. (1932). Le Tribunal des conflits juge au fond en vertu de la loi du 20 avril 1932 (212 p.). Thèse de doctorat.

Bardonnet, D. (1957). Le Tribunal des conflits, juge du fond (209 p).

Bascoulergue, A. (2014). Compétence exclusive du juge judiciaire en matière d'accidents de la circulation routière (p. 311). Actualités Juridiques du Dommage Corporel, Crim., 23 septembre $\mathrm{n}^{\circ} 13-85$.

Bleou, M. (1988). La chambre administrative de la Cour Suprême de la Côte d'Ivoire (pp. 113-146). op. cit.

Bulletin Officiel Du Ministere Du Travail, De L'Emploi Et De La Formation Professionnelle (1997). Circulaire relative aux conditions d'utilisation des véhicules de service et des véhicules personnels des agents, à l'occasion du service, Microsoft Word-véhiculesdeservice1.rtf (anticor.org).

Debbasch, C., \& Colin, F. (2010). Droit administratif(9e éd., p. 58). Economica.

Degni-Segui, R. (2009). Introduction au Droit (p. 384). EDUCI.

Degni-Segui, R. (2012). Droit Administratif Général. Tome 2: L'Action administrative (p. 448). NEICEDA.

Demba, S. (2014). Droit administratif, 2e éd., revue, corrigée et augmentée (p. 94). Credila, L'Harmattan.

Direction Generale De La Decentralisation Et Du Developpement Local (2000). Décret portant réglementation de l'acquisition, de l'utilisation et de la réforme des véhicules administratifs Cote d'Ivoire, Site Officiel de La Direction Générale de la Décentralisation et du Développement local (interieur.gouv.ci).

Djan Ziago Joseph vs Cote d'Ivoire (1986). Case n ${ }^{\circ} 44$ of $31 / 07 / 86$.

Duez, P. (1938). La responsabilité de la puissance publique (2e éd., p. 76). Dalloz.

Dufau, V. (2000). Les sujétions exorbitantes du droit commun en droit administratif (p. 
34).

Fauconnet, P. (1920). La responsabilité: Etude de la sociologie (p. 45). Librairie Felix Alcan.

Frier, P.-L., \& Petit, J. (2015). Droit administratif (10th éd., p. 93). LGDJ, Lextenso éditions.

Gaudemet, Y., Stirn, B., Dal Farra, T., \& Rolin, F. (2008). Les grands avis du Conseil d'état (3rd éd., p. 105). Dalloz.

Guillot, A. (1963). Véhicules administratifs et responsabilité publique. Bibliothèque de Droit Public. XVLII, L'Année sociologique (1940/1948-), 14, 446-448.

Guyomar, M., \& Seiller, B. (2012). Contentieux administratif(2nd éd.). Dalloz.

Laferriere, E. (1896). Traité de la Juridiction Administrative et des Recours Contentieux Tome premier (p. 53). Berger-Levrault.

Lalou, H. (1928). La Responsabilité civile principes élémentaires et applications pratiques (p. 479).

Lath, Y. S. (2011). Les caractères du droit administratif des États africains de succession française (p. 1281). RDP.

Long, M., \& Weil, P. (1984). Les Grands arrêts de la Jurisprudence administrative (p. 638). Sirey.

Mazeres, J.-A. (1962a). Véhicules administratifs et responsabilité publique (639 p.). Thèse de doctorat, Droit, Toulouse, 1960; Bibliothèque de droit public $n^{\circ} 47$.

Mazeres, J.-A. (1962b). Véhicules administratifs et responsabilité publique (pp. 620-624). Thèse de doctorat, Droit, Toulouse, Bibliothèque de droit public $n^{\circ} 47$.

McBride, J. (2009). Access to Justice for Migrants and Asylum Seekers in Europe (pp. 340-342).

Montesquieu (1979). De l'esprit des lois (The Spirit of Laws), Paris (p. 296).

Moreau, J. (1957). L'influence de la situation et du comportement de la victime sur la responsabilité administrative. Revue Internationale de Droit Comparé, 9, 802-803.

Moreau, J. (1986). La responsabilité administrative (pp. 45-48). PUF.

Odent, R. (2007). Contentieux administratif(p. 62). Dalloz.

Puigelier, C. (2020a). Alexis Forge, Essai sur l'éviction du juge en droit du travail. Revue trimestrielle de droit civil, $N^{\circ} 3,733$.

Puigelier, C. (2020b). Kamalia Mehtiyeva, La notion de coopération judiciaire. Revue trimestrielle de droit civil, $N^{\circ} 4,919$.

Saleilles, R. (1897). Les accidents de Travail et la responsabilité civile (p. 56). Librairie Nouvelle de Droit et de Jurisprudence.

Schiemann, K. (2011). The State's Liability in Damages for Administrative Action. Fordham International Law Journal, 33, Article 9.

Sieur, Q. (1950). Conseil d'Etat (p. 413). Requête numéro 99882, rec.

Tcheriatchoukine, A. (1996). La responsabilité de l'Etat du fait des dommages subis par le personnel militaire. Revue Droit et Defense, 96, 28.

Thiebaut, N. (2019). Le fait de la fonction dans le droit public de la responsabilité. Les Annales de Droit, 13, 215-256. https://doi.org/10.4000/add.1727

Truchet, D. (2007). A propos de l'évolution du droit administratif: Loi d'exception et loi de divergence. In M. J.-F. Lachaume (Ed.), Le droit administratif: permanences et convergences (pp. 633-645). Dalloz.

Vedel, G. (1961). Droit administratif(p. 98). PUF. 